\title{
Ethnic Disintegration and the Dissolution of the USSR
}

\author{
A.S. Puchenkov
}

For citation: Puchenkov A. S. Ethnic Disintegration and the Dissolution of the USSR. Vestnik of Saint Petersburg University. History, 2020, vol. 65, issue 3, pp. 826-841.

https://doi.org/10.21638/11701/spbu02.2020.308

An immense role in the collapse of the USSR was played by a whole array of factors: the public being tired of the Communist project; the massive shortages of consumer goods, which made people hate the government; the growing opposition within the Communist party to Gorbachev's reforms; the hesitation of the General Secretary who tried to rely in turn either on the right or on the left wing; the drastic fall in the living standards. The crucial role, however, was played by "the parade of sovereignties" and the Centre being too late in its attempts to address the national question. By the autumn of 1990, the President's close associates started to sense that power was slipping from Gorbachev's hands; with the fellow countrymen staying remarkably indifferent, the Soviet Union was heading towards dissolution as the ambitions of local party leaders in the constituent republics generated and cannily magnified nationalist and separatist trends. Gorbachev kept up his maneuver strategy, which put him on the verge of resignation in the spring of 1991 when his support was minimal. He seemed, though, to have managed to pull out of this dive thanks to the Soviet Union referendum held on March 17, in which the voters were asked if they considered the preservation of the USSR necessary. Eventually, however, the issue of preserving or not preserving a unified state depended directly on the position of Russia as the backbone of the Soviet Union. The study draws on the author's personal archive of original testimonies and interviews of the political figures directly involved in the events in question.

Keywords: M. S. Gorbachev, USSR, national question, disintegration.

Alexander S.Puchenkov - Doctor in History, Professor, St. Petersburg State University, 7-9, Universitetskaya nab., St. Petersburg, 199034, Russian Federation; a.puchenkov@spbu.ru

Александр Сергеевич Пученков - д-р ист. наук, проф., Санкт-Петербургский государственный университет, Российская Федерация, 199034, Санкт-Петербург, Университетская наб., 7-9; a.puchenkov@spbu.ru

This research was supported by grant No. 15-18-00119 from The Russian Science Foundation "Historical Experience of Management of Ethnic Diversity and Ethnic and Confessional Conflicts in Imperial, Soviet and Post-Soviet Russia: Interdisciplinary Research".

Исследование выполнено за счет гранта Российского научного фонда (проект № 15-18-00119, «Исторический опыт управления этническим разнообразием и этноконфессиональными конфликтами в имперской, советской и постсоветской России: междисциплинарное исследование»).

(c) Санкт-Петербургский государственный университет, 2020 


\section{Этническая дезинтеграция и распад СССР}

\section{А. С.Пученков}

Для цитирования: Puchenkov A. S. Ethnic Disintegration and the Dissolution of the USSR // Bectник Санкт-Петербургского университета. История. 2020. Т. 65. Вып. 3. С. 826-841. https://doi.org/10.21638/11701/spbu02.2020.308

Огромную роль в распаде СССР сыграла целая совокупность факторов: усталость общества от коммунистического проекта, тотальный дефицит, вызывавший безудержное раздражение населения против власти, растущая оппозиция партии реформам Горбачева, нерешительность генсека, искавшего себе опору то в правом, то в левом лагере, резкое падение уровня жизни населения. Определяющую же роль сыграл «парад суверенитетов» и постоянное запаздывание Центра с попытками решения национального вопроса. Первым крупным межнациональным конфликтом стали события в Нагорном Карабахе, где вспыхнули копившиеся на протяжении десятилетий противоречия между армянами и азербайджанцами. Впоследствии национальный фактор имел определяющее место во время событий в Вильнюсе и Тбилиси. Такое развитие событий было во многом неожиданным и для инициаторов перестройки, и для большинства советских граждан, поскольку в массовом сознании господствовало убеждение в том, что национальный вопрос в целом в СССР успешно решен. Те или иные проявления национальных противоречий расценивались как частные случаи. К осени 1990 г. в ближайшем окружении М. С. Горбачева появилось ощущение, что власть ускользает из рук президента СССР. При удивительном равнодушии общества распадался и Советский Союз: амбиции местных партийных лидеров порождали и искусно раздували национализм и сепаратистские течения. Горбачев продолжал тактику лавирования, которая подвела его весной 1991 г. к угрозе отставки. База поддержки союзного президента сократилась до минимума. В такой ситуации Горбачеву удалось, казалось бы, выйти из политического пике - способствовали этому результаты Всесоюзного референдума 17 марта, на котором ставился вопрос о существовании обновленного Советского Союза. Вопрос сохранения или несохранения Советского Союза как государства был напрямую связан с позицией государствообразующей республики - Российской Федерации. Исследование основано на уникальных свидетельствах непосредственных участников событий из личного архива автора.

Ключевые слова: М. С. Горбачев, СССР, национальный вопрос, дезинтеграция.

Mikhail Gorbachev's rise to power in the USSR in 1985 led to unprecedented changes not only in the Soviet society, but also in the whole world. The new leader's policy of perestroika brought into play the kind of dynamics that affected the very backbone of the immense country - the national issue.

This turn of events was expected neither by those who implemented perestroika nor by most Soviet citizens due to the prevalent common belief that the national question in the USSR had been solved fairly successfully. Whatever national tensions occurred, they were viewed as individual instances. All the more striking it was to everyone, including the top officials, that shortly after perestroika was introduced, the USSR saw the explosion of the "national bomb" when the republics started to express themselves politically and the process was unstoppable. It eventually resulted in the notorious Belovezh Accords, which were the bottom line of the history of the USSR. Was it predetermined? Was Gorbachev 
leading the country the right way? Were changes necessary? Was the USSR bound to collapse? ${ }^{1}$

The euphoria about the accession of a young and highly enthusiastic leader did not last. The long-standing problems, which had been thoroughly concealed by the Soviet ideology, revealed themselves under glasnost. The ethnic issue was no exception and made itself evident as early as the end of 1986, during the December unrest in Alma-Ata that was suppressed by force. It became obvious that the more remote areas were no longer willing to blindly follow the command of the Centre.

The path to further and more acute ethnic strife was paved by Nagorno-Karabakh, which, in the words of Gorbachev, "blew up" in early $1988^{2}$. Predominantly ethnic Armenian (with $77 \%$ Armenians and $21 \%$ Azerbaijanis), the autonomous region within Azerbaijan Soviet Socialist Republic had long wanted to be part of Armenia, which was strongly objected to by the Azerbaijani authorities whose policies were aimed at keeping Nagorno-Karabakh separated and culturally isolated from Armenia ${ }^{3}$. In October 1987 the Karabakh Armenians started a public and persistent campaign for reunification with Armenia. The authorities and the people of Azerbaijan were against the idea of losing a large part of their territory. Each side had its reason. The situation was heating up fast. In January 1988 the first few hundred Azerbaijani families left Armenia. Some of the refugees settled in the Azerbaijani town of Sumgait. In February, the extremists from among the refugees initiated a pogrom that targeted the Armenian population and left $26 \mathrm{Ar}$ menians and 6 Azerbaijanis dead. This resulted in a mass migration of Armenians from Azerbaijan, and of Azerbaijanis - from Armenia ${ }^{4}$. The Centre's response complied with the stance of the General Secretary: "let the Armenians and Azerbaijanis come together and take their own decision; we (in Moscow) will accept whatever choice they make"5; Gorbachev urged his Politburo colleagues to use "political methods"6. Though largely justified and logical, under the circumstances in place such an attitude led the Armenian and Azerbaijani political elites to believe that the central government's position was either pro-Azerbaijani or pro-Armenian, respectively. Willing to act as a peace-maker, the central government was in fact creating a deadlock by fueling, unintentionally, the escalation of conflict in the region.

On 7 December 1988 a devastating earthquake in Armenia broke out. The pain of the Armenian nation was felt by every Soviet person. For probably the last time in the history

${ }^{1}$ See controversy on this issue in recent publications: Pikhoia R. G. O periodizatsii sistemnogo krizisa Sovetskogo Soiuza // Rossiiskaia istoriia. 2019. No.2. P.3-39; Zubok V.M. Krizis, reformy i razrushenie SSSR // Rossiiskaia istoriia. 2019. No. 2. P. 30-39; Zubok V.M. Nesostoiavshaiasia imperiia: Sovetskii Soiuz v kholodnoi voine ot Stalina do Gorbacheva. Moscow, 2011. P.400-485; Shubin A. V. Osnovnye problemy i etapy istorii perestroiki // Rossiiskaia istoriia. 2019. No. 2. P.39-51; Puchenkov A. S.: 1) Pobedy i porazheniia Mikhaila Gorbacheva // Rossiiskaia istoriia. 2019. No. 2. P. 205-213; 2) Zhizn' i vremia Anatoliia Cherniaeva // «My nazyvali ego grafom»: Pamiati Anatoliia Sergeevicha Cherniaeva. Vospominaniia sovremennikov, dokumenty, publikatsii / sost. D. A. Belanovskii. Moscow, 2019. P.525-564; Taubman U. Gorbachev. Ego zhizn' i vremia. Moscow, 2019.

2 Gorbachev M. S. Poniat' perestroiku... Pochemu eto vazhno seichas. Moscow, 2006. P. 151.

${ }^{3}$ Ialyshev R. A. Problema novogo soiuznogo dogovora i ego roli v raspade SSSR: dis. ... kand. ist. nauk. St. Petersburg, 2011. P. 41.

${ }^{4}$ Ibid. P. 42.

${ }^{5}$ Gorbachev M. S. Poniat' perestroiku... P. 151.

6 Vystuplenie M.S. Gorbacheva na Politbiuro. 3 marta 1988 g. // V Politbiuro TsK KPSS... Po zapisiam Anatoliia Cherniaeva, Vadima Medvedeva, Georgiia Shakhnazarova (1985-1991) / sost. A.Cherniaev, A. Veber, V.Medvedev. Izdanie 2-e, ispravlennoe i dopolnennoe. Moscow, 2008. P. 298. 
of the USSR the world could see that the "brotherhood of Soviet nations" was not a phantom: Armenia received a colossal aid from the Centre, free of political strings ${ }^{7}$, and volunteers flocked from all over the world. For the last time, Gorbachev and Ryzhkov worked efficiently as a concerted tandem, both the General Secretary and the Prime Minister gave the small republic an enormous support ${ }^{8}$, travelling across the ruined Armenia in a simple red Ikarus bus ${ }^{9}$. Armenia was visited at the time by nearly every top official who felt pure human compassion at the sight of the staggering destruction in the earthquake-ridden towns ${ }^{10}$. What the world showed towards Armenia was the phenomenon of compassion, sympathy, and positive relief effort, which would have been completely impossible not too long before.

As for the head of state, the writer of these lines has been told by Artashes Geghamyan, the then mayor of Yerevan, that Gorbachev was astounded that almost every person who saw him amidst the ruins asked not to help with the provision of housing, but to solve the issue of the territorial affiliation of Nagorno-Karabakh in favour of Armenia ${ }^{11}$. Nagorno-Karabakh set the entire Soviet Union in motion and, according to Viacheslav Mikhailov, head of the Inter-Ethnic Relations Department of the CPSU Central Committee, provided "a formula for putting pressure on the authorities: the local nationalists in the republics could see that if a rally numbered over 10 thousand people, the authorities hesitated to take any action"12. His words were echoed by Arkadii Volskii, Gorbachev's special emissary in Nagorno-Karabakh: "In Nagorno-Karabakh we faced the first largescale ethnic conflict... Owing to history and the temper of the local population, a major war was becoming imminent..."13

The year 1988 was marked by growing ethnic tensions: in the Baltics, in Nagorno-Karabakh... Soon the periphery of the USSR would literally "blow up" the Soviet empire, and the Centre would fail to catch up on the events.

In the small hours of April 9, 1989, an unauthorized demonstration in the capital of Soviet Georgia was dispersed by the army resulting in 17 deaths. The parliamentary commission that investigated the tragedy concluded that the leaders of the Communist Party and the government of the republic had been fully informed about the events, and that the army had used chemical substances against the demonstrators ${ }^{14}$. Nearly all of the victims died of asphyxia (suffocation), in other words, they died in a stampede ${ }^{15}$. The Tbilisi tragedy, responsibility for which was assumed neither by the head of state nor by

${ }^{7}$ Ambartsumian S. A. Tri goda na predele liubvi i smerti. Erevan, 1991. P. 67.

8 Already in the first days, 87 thousand people were evacuated. (Dnevniki predsedatelia Soveta Ministrov SSSR N. I. Ryzhkova, 1985-1990 gg.) // Rossiiskii gosudarstvennyi arkhiv sotsial'no-politicheskoi istorii (RGASPI). F. 653. Op. 1. D. 553. Dnevnikovaia zapis' N. I. Ryzhkova ot 21.12.1988. S.2).

${ }^{9}$ Rossiiskaia gazeta. 2018. 6 dekabria.

10 Interv'iu V. G. Zakharova, ministra kul'tury SSSR v 1986-1989 gg. (Moscow, 17.12.2017) // Arkhiv avtora.

${ }^{11}$ Interv'iu A. M. Gegamiana, mera Erevana v 1989-1990 gg. (Erevan, 02.09.2018) // Arkhiv avtora.

12 Interv'iu V.A. Mikhailova, v 1987-1991 gg. zaveduiushchego otdelom po mezhnatsional'nym otnosheniiam TsK KPSS, v 1995-2000 - ministra Rossiiskoi Federatsii po delam natsional'nostei (Moscow, 24.01.2018) // Arkhiv avtora.

13 Zavada M., Kulikov Iu. Poprobuite menia ot veka otorvat'.. Dialogi s Arkadiem Vol'skim. Moscow, 2006. P. 101.

14 Materialy deputatskoi komissii po sobytiiam v Tbilisi // Gosudarstvennyi arkhiv Rossiiskoi Federatsii (GARF). F. 9654. Op. 2. D. 65. S.21-34.

${ }^{15}$ Interv'iu S. B. Stankevicha, narodnogo deputata SSSR (Moscow, 01.04.2019) // Arkhiv avtora. 
anyone else ${ }^{16}$, discredited both Gorbachev and the Soviet Army and the Party leaders, and thus entitled Georgia to claim withdrawal from the USSR. Gorbachev and the like-minded officials learned their lesson from the Tbilisi "bloody Sunday": "From now on the army must not be involved in such events unless mandated by the Politburo"17.

In the Soviet Union in general, things were getting progressively worse in 1989. Unforeseen by Gorbachev, national separatism was becoming more and more powerful and was making itself increasingly evident. ${ }^{18}$ "The Centre was essentially unprepared for the outburst of national self-identification, additionally augmented by clan, tribal, and proprietorial antagonisms. This was Gorbachev's major misjudgment - the national factor was not taken into account. There was a belief in the existence of a 'Soviet nation'”, remembered Anatolii Cherniaev, Gorbachev's adviser ${ }^{19}$. The year 1990 was not an easy one either for the Soviet Union or for Gorbachev. The country was falling apart. It was all at once: the economic turmoil, the Party unwilling to be associated with the reformer General Secretary, El'tsin clearly aiming at separating Russia from the Centre, and the people being tired of hapless reforms. Gorbachev's team were in the wake of mainstream opinions: they did not approve of his hopping from "right" to "left". By that time, Gorbachev's associates had begun to realize that both the Politburo and the CPSU Central Committee were losing their power: the periphery regions were splitting off in an uncontrollably rapid manner. Trying to hold the country together, Gorbachev claimed a special mandate for himself. Given the clear unpopularity of the Party with the public, he insisted that it was necessary to establish the post of President of the USSR as a figure symbolizing the Centre.

The Third Congress of the People's Deputies of the Soviet Union elected Gorbachev President of the USSR, yet his victory was not convincing. His refusal to run in the national election became his biggest political blunder. According to Boris El'stin's close associate Gennadii Burbulis, "President Gorbachev's legitimacy was rather vulnerable, of which all the later events are the evidence" 20 .

The main issue for the Soviet Union of 1990 was the preparation of the New Union Treaty. The ominous parade of sovereignties pioneered by Russia with its declaration of sovereignty that brought about catastrophic consequences and inspired similar declarations in Uzbekistan, Moldova, the Ukraine, Belarus, Turkmenistan, Armenia, Tajikistan, Kazakhstan, and Kyrgyzstan, and prior to those - in Georgia, Latvia, and Estonia, was calling for a new kind of union to hold the republics together. At the same time, gaining strength was another sovereignization: the autonomous republics wanted their status to be raised to that of union republics. In response to that, Boris El'tsin, who was elected Chairman of the Presidium of the Supreme Soviet of the Russian SFSR in 1990 despite Gorbachev's pressure on the people's deputies, famously said that the peoples of the Russian SFSR could take "the share of power which they themselves could swallow". The election of El'tsin as chairman of the Russian parliament was "a landmark victory. Everyone interpreted it as a start of an open war against Gorbachev", remembers El'tsin's associate

16 Ligachev E. K. Zagadka Gorbacheva. Novosibirsk, 1992. P. 224-237.

17 V Politbiuro TsK KPSS... P. 486.

18 Onikov L. A. KPSS: Anatomiia raspada. Vzgliad iznutri apparata TsK. Moscow, 1996. P. 115.

19 Cherniaev A. Gorbachev ochen' dobryi // Moskovskii komsomolets. 1995. 11 aprelia.

${ }^{20}$ Interv'iu G.E. Burbulisa, narodnogo deputata SSSR, v 1990-1992 - gosudarstvennogo sekretaria RSFSR (Moscow, 11.02.2019) // Arkhiv avtora. 
Sergey Filatov ${ }^{21}$. There developed another centre of power represented by El'tsin, which eventually proved fatal for the country ${ }^{22}$.

By the end of 1990, declarations of sovereignty had been adopted by all the autonomous republics, autonomous districts, and autonomous provinces within the Russian SFSR ${ }^{23}$. The struggle "for the Kremlin" between El'tsin and Gorbachev now entered a "hot" phase. "Russia's hasty adoption of sovereignty was a certain point of no-return. Russia was the mainstay, the backbone of the USSR. Now the broken backbone caused a total collapse. A torrential sovereignization was gathering pace. Uzbekistan, the Ukraine, Belarus, Kazakhstan, let alone those giants - the autonomous republics - started talking about sovereignty", wrote Rafik Nishanov ${ }^{24}$. He was echoed by Nikolai Ryzhkov: "I believe it was then, in the summer of 1990, that the foundation of the Union's dissolution was laid. I have nothing against sovereignty, especially that of Russia. I believe Russia should have been given more rights, but the line of destruction should not have been crossed..." [italics added $]^{25}$. According to the well-known journalist Leonid Radzikhovskii, "Russia declared its INDEPENDENCE FROM THE USSR [emphasis in original]. The Soviet Union received a DEADLY BLOW: "the backbone was taken out of the body"26.

As it was rightfully noted by the St. Petersburg historian V. V. Kalashnikov, "the struggle for power between the two leaders resulted in a battle of laws and sovereignties and in many ways facilitated the dissolution of both the USSR and of Russia"27. Still, does it really come down to El'tsin alone? "The Soviet Union was being ripped to pieces by everyone, not just by El'tsin. The First Secretary in each republic wanted full authority. Nobody thought about the consequences, and nobody wanted to be accountable to Gorbachev", remembered M. N. Tolstoi, a people's deputy of the Russian SFSR ${ }^{28}$.

The country was falling apart, yet, to the credit of the President of the USSR, Gorbachev worked tirelessly towards keeping it united up until his resignation. The "parade of sovereignties" was pioneered by Lithuania, which declared itself an independent state on March 11, 1990, and proclaimed the constitution of the USSR invalid on its territory. The Third Congress of the People's Deputies of the Soviet Union, which elected Gorbachev President of the USSR, announced it an illegitimate action for Lithuania to take, and called the Act of Independence illegal ${ }^{29}$. In the following months the "Baltic model" served as inspiration to other republics of the USSR, and was to this or other extent copied by them ${ }^{30}$.

${ }^{21}$ Interv'iu S. A. Filatova, narodnogo deputata RSFSR, sekretaria Prezidiuma Verkhovnogo Soveta RSFSR, v 1993-1996 gg. (Moscow, 22.03.2019) // Arkhiv avtora.

${ }^{22}$ Interv'iu V.I. Alksnisa, narodnogo deputata SSSR (Poselok g. t. Tuchkovo, Moskovskaia obl., 02.04.2019) // Arkhiv avtora.

${ }^{23}$ Kalashnikov V. Demontazh SSSR: vzgliad chetvert' veka spustia // Sankt-Peterburgskie vedomosti. 2016. 12 avgusta.

24 Derev'ia zeleneiut do metelei: Rafik Nishanov rasskazyvaet Marine Zavade i Iuriiu Kulikovu. Moscow, 2012. P. 322-323.

${ }^{25}$ Zapisi besed N. I. Ryzhkova s sotrudnikami Guverovskogo instituta voiny, revoliutsii i mira. (SShA). 1992-1994. // RGASPI. F.653. Op. 1. D.519. S. 176.

${ }^{26}$ Radzikhovskii L. Luchshe men'she da luchshe // Rossiiskaia gazeta. 2010. 15 iiunia.

27 Kalashnikov V. Pravo - iskusstvo dobra i spravedlivosti // Pravda. 1992. 18 noiabria.

${ }^{28}$ Interv'iu M.N. Tolstogo, narodnogo deputata RSFSR (St. Petersburg, 25.10.2018) // Arkhiv avtora.

${ }^{29}$ Kalashnikov V. Demontazh SSSR: vzgliad chetvert' veka spustia...

30 Interv'iu G.S. Ostroumova, rukovoditelia sekretariata Prezidenta SSSR (Moscow, 06.02.2018) // Arkhiv avtora. 
According to Anatolii Cherniaev, "Gorbachev sincerely believed that the Lithuanians were not interested in the dissolution of the Soviet Union. He did not realize that they were prepared to pull in their belts and to make any sacrifices in order to assert their independence. This underestimation of the national instinct - irrational, of course, but overriding (which can be seen not only in the post-Soviet space) - played its role" ${ }^{31}$. It is noteworthy that in the opinion of the USA the Baltics had a special status: the USA always stated that the Baltics were incorporated into the Soviet Union illegally and thus never recognized them as legitimate constituent republics ${ }^{32}$.

By the autumn of 1990, the President's close associates started to sense that power was slipping from Gorbachev's hands; with the fellow countrymen staying remarkably indifferent, the Soviet Union was heading towards dissolutions; the ambitions of local party leaders generated and cannily magnified nationalist and separatist trends.

The Centre was too late with the solution to the national issue, which was fatal to the Soviet Union ${ }^{33}$, and because of the "nationalist landslide" the ground was literally slipping away underneath Gorbachev's feet ${ }^{34}$. Under these circumstances, Gorbachev and his team were assiduously developing the draft of the New Union Treaty. By then, "some of the republics had already declared their intention to withdraw from the USSR... Gorbachev had to urge and persuade them: do not go! It will make things worse for you! But, despite his status as President, his arguments were ignored", remembered Anatolii Cherniaev ${ }^{35}$.

The year 1990 was drawing to a close - the year that was wasted for the country on the brink of the precipice. It was in that year that the process of the USSR's dissolution became irreversible. "By 1991 the whole structure of perestroika was sliding apart, like the ski-clad feet do off the ski-track", ${ }^{6}$ - it was obvious that the Soviet Union could be saved only by emergency measures. How, when, and who would take them - that was the problem. The President's associates were aware that Gorbachev was losing power; according to Alexander Bessmertnykh, the Minister of Foreign Affairs of the USSR, Gorbachev "was slightly panicking, the ground was getting too hot under his feet" ${ }^{37}$. Gorbachev faced a difficult decision; the very course of events and the associates who appeared loyal at the time - V. I. Boldin, V. A. Kriuchkov, O. D. Baklanov, D. T. Yazov - were virtually pushing him towards Stalin's pattern. He had a feeling that "the public failed to assimilate so many changes", while the democratic flank was not able to assess the situation appropriately in terms of statesmanship. That was why Gorbachev decided to rely on the "right wing" part of his team, who were persuading him to demonstrate "a strong hand" 38 . The President's "new course" was met extremely negatively by the democratic wing of Gorbachev's team.

Still in 1990, when he saw the growing gap between the republics and the Centre and was apprehensive that the "Lithuanian scenario" might repeat itself, Gorbachev declared that it was necessary to sign a New Union Treaty. The draft was being prepared during

31 Cherniaev A. Gorbachev ochen' dobryi...

32 Interv'iu A. A. Bessmertnykh, v ianvare - avguste 1991 g. - ministra inostrannykh del SSSR, chlena TsK KPSS (Moscow, 21.03.2019) // Arkhiv avtora.

33 Gorbachev M.S. V meniaiushchemsia mire. Moscow, 2018. P. 199.

34 Grachev A. S. Gibel' sovetskogo “Titanika”: Sudovoi zhurnal. Moscow, 2015. P. 194.

35 Cherniaev A.S. Shest' let s Gorbachevym. Moscow, 1993. P. 364.

36 Interv'iu A.S. Gracheva, v 1991 godu - chlena TsK KPSS, v avguste - dekabre 1991 g. — presssekretaria Prezidenta SSSR M. S. Gorbacheva (Moscow, 05.07.2018) // Arkhiv avtora.

${ }^{37}$ Interv'iu A. A. Bessmertnykh...

${ }^{38}$ Interv'iu A.S. Gracheva... 
the unrests in the Baltics and the South Caucasus, but what increased the risk of dissolution tenfold was the situation in Russia: Chairman of the Supreme Soviet of the Russian SFSR Boris El'tsin, who hated Gorbachev, considered the President of the USSR, i. e. the Centre, the only obstacle to absolute power. In reality, what made the actual signing of the Treaty impossible in 1990 was the position of Russia (i. e. El'tsin's) blocking Gorbachev's initiative. The further fragmentation of the country and a drastic reduction in his power encouraged Gorbachev to swing to the right, towards the adherents to strong arm tactics in keeping the republics, the Baltics in particular, within the USSR, but the January 1991 events in Vilnius not only discredited the head of state before the democratically-minded public and the global community, but also left Gorbachev himself shocked as he interpreted the January 13 bloodshed as a manufactured incident aimed against him as President ${ }^{39}$.

The democratically-minded public felt that the Vilnius events posed a threat to the reforms; the tanks in the streets of Vilnius were seen as a warning of a forthcoming dictatorship and as a rehearsal of a possible coup in Moscow. The credibility of the central government and of Gorbachev personally was now eroded, while the local national "leaders" became immensely popular since they were viewed as the only hope to protect the republics from the punitive actions by the Centre. However, Gorbachev was in fact trying to find an acceptable method to preserve the country intact and to keep the situation under control. Politically, the events in Vilnius were his defeat: the 1990 Nobel Peace Prize winner was no longer admired by the Russian democratic community, whereas the President, in his turn, stated his willingness to use strong arm tactics in order to defend the laws of the Union but was not able to take the responsibility for it - as a result, the security officials felt "betrayed" and blamed him for being passive and dysfunctional. Gorbachev's associates, for their part, strongly believe to this day that he did not order the military forces to take action in Vilnius ${ }^{40}$.

Gorbachev kept up his maneuver strategy, which put him on the verge of resignation in the spring of 1991 when his support was minimal. He seemed, though, to have managed to pull out of this dive thanks to the referendum on the future of the Soviet Union held on March 17, in which the voters were asked if they considered the preservation of the USSR necessary. Gorbachev went all-in: if the voters had answered the question negatively, he would have had to resign. He spoke about being prepared to leave his post in that case in the presence of his adviser Anatolii Cherniaev ${ }^{41}$.

On March 17, 1991, a Soviet Union referendum took place for the first time in history. $76,4 \%$ of the voters answered "yes" to the question put to them - "do you consider necessary the preservation of the Union of Soviet Socialist Republics as a renewed federation of equal sovereign republics in which the rights and freedom of an individual of any ethnicity will be fully guaranteed?"42. The referendum itself and the wording of the question had a number of failings; suffice it to say that the referendum was boycotted by six out of fifteen constituent republics (the Baltics, Armenia, Georgia, and Moldova) because they did not see any future for themselves within the renewed Union. The referendum

39 Gorbachev M. S. V meniaiushchemsia mire. P. 202.

40 Interv'iu V.N. Ignatenko, press-sekretaria Prezidenta SSSR M.S. Gorbacheva v 1990-1991 gg. (Moscow, 17.10.2018) // Arkhiv avtora.

${ }^{41}$ Cherniaev A.S. Dnevnikovaia zapis' ot 23 iiulia 1991 g. // Cherniaev A. S. Sovmestnyi iskhod. Dnevnik dvukh epokh. 1972-1991 gody. Moscow, 2009. P. 965.

42 Protokol Tsentral'noi izbiratel'noi komissii referenduma SSSR // GARF. F. 7522. Op. 13. D. 134. S. 6. 
took place in the situation where the authorities virtually acknowledged that preserving the USSR as a union of 15 republics was not possible.

The referendum was undoubtedly a timely and powerful step taken by Gorbachev ${ }^{43}$; and he was elated by the results ${ }^{44}$ which showed that the majority of the Soviet people did want to preserve the country intact ${ }^{45}$. The president's position was now stronger. "I suppose that had it not been for the referendum, there would have been no Novo-Ogaryovo sessions, which helped to diffuse the tension for some time and to create the conditions to overcome the crisis", Gorbachev reasonably states ${ }^{46}$. Thanks to the outcome of the referendum, there began a months-long Novo-Ogaryovo process ${ }^{47}$, in which Gorbachev demonstrated an exceptional art of political maneuvering and achieved a serious number of halfway tactical victories.

On April 23, 1991, a day before the Plenary Session of the CPSU Central Committee, Gorbachev succeeded in holding a meeting with the leaders of nine republics and in persuading them to recognize the New Union Treaty as a first priority. The result was the adoption of the famous " $9+1$ " Agreement: the nine republics and the Centre represented by the President began to develop the text of the new treaty. The situation being difficult for Gorbachev, the republics found it would be in their own interest to support the President in order to avoid an unpredictable response from the security officials ${ }^{48}$.

The " $9+1$ " Agreement gained a resonance among the public and gave certain hopes that the situation in the country would soon become stable ${ }^{49}$. The outcome of the March referendum provided a political and legal ground for signing the New Union Treaty. Yet, the first sessions of the Novo-Ogaryovo process revealed that El'tsin was not going to let this happen before the Russian SFSR presidential election scheduled for June $12^{50}$; there was a strong mutual mistrust between the two leaders ${ }^{51}$. El'tsin's associates were aware that his confrontation with Gorbachev was not over yet and "that ' $9+1$ ' was a mere truce" 52 . In fairness it must be said that it was in the final months preceding the August Coup that there was a trend towards the establishment of a status quo between the two very influential politicians: "Gorbachev and I suddenly sensed", El'tsin wrote in his memoir, "that our interests finally coincided; that we were satisfied with the roles we had. Gorbachev had his senior position, and I had my independence. It was a perfect solution for both" 53 . The position of Nursultan Nazarbayev, the wise Kazakh leader, who acted as a sort of "breakwater" in the conflicts between the republics and the Centre, also reduced the intensity of the situation: at their confidential meeting at Novo-Ogaryovo Gorbachev, El'tsin, and

${ }^{43}$ Interv'iu A.S. Dzasokhova, v 1991 - chlena Politbiuro, sekretaria TsK KPSS (Moscow, 14.11.2018) // Arkhiv avtora.

${ }^{44}$ Interv'iu V.N. Ignatenko, v 1990-1991 — press-sekretaria Prezidenta SSSR (Moscow, 17.10.2018) // Arkhiv avtora.

45 Ialyshev R. A. Problema novogo soiuznogo dogovora i ego roli v raspade SSSR: avtoref. dis. ... kand. ist. nauk. St. Petersburg, 2011. P. 20.

46 Gorbachev M.S. V meniaiushchemsia mire. P. 203.

47 Brown A. The Gorbachev Factor. Oxford, 1997. P. 286.

${ }_{48}$ Kravchuk L. M. Maemo te, shcho maemo: Spogadi i rozdumi. Kiev, 2002. P. 81.

49 Stankevich Z. A. Sovetskii Soiuz. Obryv istorii. Moscow, 2016. P. 257.

${ }^{50}$ Kalashnikov V. Demontazh SSSR: vzgliad chetvert' veka spustia...

${ }^{51}$ Interv'iu A. A. Bessmertnykh...

${ }^{52}$ Interv'iu G. V.Starovoitovoi, 22 maia 1991 g. // Karaulov A. V. Vokrug Kremlia - 2. Kniga politicheskikh dialogov. Moscow, 1992. P. 203.

${ }^{53}$ El'tsin B. N. Zapiski prezidenta. Moscow, 1994. P. 54. 
Nazarbayev decided to start the process of signing the treaty as early as on August 20. An obvious problem was the name of the country they agreed on: the Union of Soviet Sovereign (not Socialist!) Republics. The name had long been debated, and the abbreviation was eventually settled on "for the sake of the harmony of sounds, rather than the content" 54 . That alone was worrisome for both the party elite and the Supreme Soviet of the USSR, who appealed to the results of the referendum that confirmed the willingness to preserve the Union of Soviet Socialist Republics. Whether the Novo-Ogaryovo process was "unconstructive" and the draft of the Treaty was "of poor quality, controversial", as Ruslan Khasbulatov thinks ${ }^{55}$, or whether, as Vladimir Egorov, Gorbachev's aide, believes, it was a desperate "attempt to correct the colossal blunder of 1922, with the country's division being based on the national, rather than administrative principle"56, is hard to say now.

Chairman of the Presidium of the Supreme Soviet Anatolii Luk'ianov's standpoint was quite logical: according to him, the name of the country and the main points of the Treaty had to reflect "the outcomes of the Soviet Union referendum, in which an overwhelming majority of the people supported the idea of preserving the USSR as a renewed federation of equal sovereign republics" ${ }^{57}$ His opinion was shared by the Supreme Soviet of the USSR. The latter, for its part, was mystified at why the President at some point excluded the supreme body of power from developing the draft of the Treaty, and why he did not inform the Supreme Soviet about the amendments made by the participants of the Novo-Ogaryovo process ${ }^{58}$. The news about it reached the ears of the President, but he was firm in pursuing his agenda of signing the Treaty as soon as possible, even against the legal odds.

The ultimate priority of the Treaty was expressed in Gorbachev's formula: a powerful Union - powerful republics ${ }^{59}$. President of the USSR "was himself in charge of developing the draft" 60 . He invited the best experts - Z.A. Stankevich, Yu. M. Baturin, A. A. Sazonov, V.N.Kudriavtsev - who developed various versions of the draft. The group of experts was very limited; in accordance with the old Communist party tradition, in the evening, when his work of the day was done, Gorbachev in person inspected and reviewed what the experts had produced during the day. The development of the draft was fully and solely controlled by Gorbachev and his apparatus: neither the CPSU Central Committee, nor the Security Council, nor the Politburo were notified of the content of the negotiations at the presidential residence. It was deliberately arranged so: President and the General Secretary, embodied in one person, wished to inform his party and government subordinates only upon signing the treaty; this being said, Gorbachev emphasized that in Novo-Ogaryovo he "acted as president", and not as General Secretary ${ }^{61}$. In those most

${ }^{54}$ Interv'iu Iu. M. Baturina, v 1991 godu — sotrudnik apparata Prezidenta SSSR, ekspert po podgotovke novogo Soiuznogo Dogovora (Moscow, 30.06.2018) // Arkhiv avtora.

55 Interv'iu R. I. Khasbulatova, v 1990-1991 gg. - pervogo zamestitelia Predsedatelia Verkhovnogo Soveta RSFSR, s oktiabria 1991 g. - predsedatelia Verkhovnogo Soveta RSFSR (Moscow, 12.08.2016) // Arkhiv avtora.

56 Interv'iu V. K. Egorova, pomoshchnika prezidenta SSSR (Moscow, 06.02.2018) // Arkhiv avtora.

57 Luk'ianov A.I. V vodovorote rossiiskoi smuty (razmyshleniia, dialogi, dokumenty). Moscow, 1999. P. 53.

58 Atamanchuk G. V. Novoe gosudarstvo: poiski, illiuzii, vozmozhnosti. Moscow, 1996. P. 36.

59 Shakhnazarov G. Kh. S vozhdiami i bez nikh. Moscow, 2001. P. 417.

${ }^{60}$ Neokonchennaia istoriia. Besedy Mikhaila Gorbacheva s politologom Borisom Slavinym / avtorsost. B. Slavin. Moscow, 2001. P. 54.

${ }^{61}$ Falin V.M. Bez skidok na obstoiatel'stva: Politicheskie vospominaniia. Moscow, 1999. P. 413. 
complicated and arduous discussions he, according to V.V.Bakatin, "displayed superhuman patience" 62 , going back again and again to the various disputable points of the Treaty. The Party was barred from participating in the Novo-Ogaryovo process. The high-ranking Central Committee officials heard some vague speculations about Gorbachev making concessions to the republics ${ }^{63}$ but they did not have a clear idea of either the course of the negotiations or the content of the draft approved by the leaders of the republics and ready to be signed ${ }^{64}$; the CPSU Central Committee were thus "outspokenly critical" of the Novo-Ogaryovo process ${ }^{65}$.

The situation sometimes turned into a sad joke: for example, Secretary of the CPSU Central Committee and member of the Politburo Alexander Dzasokhov was familiarized with the draft "for old friendship's sake and privately" by the head of the president's apparatus G. I. Revenko ${ }^{66}$.

On behalf of the president's apparatus, the work of developing the text of the Treaty was supervised by G. Kh. Shakhnazarov and G.I. Revenko. The progress was very slow and difficult: "after each Novo-Ogaryovo session something important for the Union was lost... The republics had the upper hand", remembered Yu. M. Baturin who was an active participant in developing the draft ${ }^{67}$. In some ways, he believed, the New Union Treaty was similar to "divorce proceedings with a pending date" 68 .

What the relations between the Centre and the republics would look like, what the Centre's and the President's prerogatives would be, and which of the Centre's rights would now belong to the republics, remained shrouded in mystery until the very last moment. While settling for, in the words of Anatolii Cherniaev, "a de facto free confederation" 69 , Gorbachev must have understood that the Treaty's provisions were politically vulnerable, and that the central structures in the new union were loose, but he must have hoped to later give them more political substance to suit his needs ${ }^{70}$. Being a hopeless optimist, Gorbachev, as he himself confessed, remained too positive and confident even in $1991^{71}$. Did his confidence have no solid foundation? To begin with, Gorbachev did not believe that the Union could possibly dissolve ${ }^{72}$, the very idea went against his mindset and his expectations, and what is more, it made no sense to him - there was, in his opinion, no benefit for the republics. Consequently, he was assured that the republics would not attempt to withdraw from the Union.

62 Bakatin V. V. Doroga v proshedshem vremeni. Moscow, 2015. P. 322.

${ }^{63}$ Interv'iu V. V.Kalashnikova, v iiule - avguste 1991 g. - sekretaria TsK KPSS (St. Petersburg, 31.10.2018) // Arkhiv avtora.

${ }^{64}$ Interv'iu B. P. Guseletova, v 1990-1991 gg. chlena TsK KPSS (Moscow, 19.12.2018) // Arkhiv avtora.

${ }^{65}$ Nazarbaev N. Liubye pogranichnye pretenzii segodnia - eto neminuemoe krovoprolitie // Nezavisimaia gazeta. 1992. 6 maia.

${ }^{66}$ Interv'iu A. S. Dzasokhova...

${ }^{67}$ Interv'iu Iu. M. Baturina...

68 Ibid.

69 Cherniaev A.S. Dnevnikovaia zapis' ot 3 avgusta 1991 g. // Cherniaev A. S. Sovmestnyi iskhod. P.969.

70 Interv'iu A. Ia. Degtiareva, v 1991 godu - zaveduiushchim ideologicheskim otdelom TsK KPSS (Moscow, 14.03.2017) // Arkhiv avtora.

${ }^{71}$ Gorbachev M. V 1991 godu ia byl slishkom samouveren // Nezavisimaia gazeta. 1995. 29 dekabria.

${ }^{72}$ Interv'iu Iu. M. Baturina, sotrudnika apparata Prezidenta SSSR, eksperta po podgotovke novogo Soiuznogo dogovora (Moscow, 30.06.2018) // Arkhiv avtora. 
The Treaty was scheduled to be disclosed for signing on August 20, 1991. Its final version was "highly controversial in nature but provided a good chance of preserving the union of at least nine republics. It could have served as a foundation for either a federation or a confederation, depending on who and with what purpose would implement it", writes the St Petersburg historian R. A. Yalyshev ${ }^{73}$. There are indications that if the Treaty had been signed, the union would have been preserved in this form or another - with Gorbachev or without him ${ }^{74}$. The August 15, 1991 issue of the Pravda newspaper carried the draft of the Treaty of Union of Sovereign States that had been approved on July $23^{75}$. "A lousy document, but it has to be signed even though it's not brilliant. If it gets signed, we can hold on", - such was the answer of Viacheslav Mikhailov, head of the Inter-Ethnic Relations Department of the CPSU Central Committee when he was asked by O.S. Shenin, Secretary of the CPSU Central Committee, of his opinion of the published draft ${ }^{76}$. The Union failed to "hold on" - all the agreements between the Centre and the republics were destroyed as a result of the August Coup, and the path to the dismantling of the USSR was now open.

It has been over a quarter of a century since the August Coup of 1991, which transformed this country utterly, and to some extent - transformed the whole world. Many of the coup-related questions will probably never be answered. One thing is obvious, though: the coup attempt, which caused the collapse of the Union, could have been avoided. So believed, among others, Anatolii Cherniaev, the President's aide. According to him, "had Gorbachev not taken a holiday, there would have been no coup" 77 . Of the same opinion are Secretary of the CPSU Central Committee V.V.Kalashnikov and Gorbachev's press secretary V.N. Ignatenko. They both emphasize that Gorbachev would have remained in power, had it not been for his journey to the Crimea and the subsequent coup attempt; they both point out that Gorbachev and his team, most of whom took their holiday at the same time with the boss, were all extremely tired ${ }^{78}$. Gorbachev himself admits that his holiday was highly untimely ${ }^{79}$. Before the holiday he gave the impression of being tired to death and at the same time of being satisfied: according to Alexander Bessmertnykh, who was then Minister of Foreign Affairs of the USSR, Gorbachev felt that "a considerable work had been done, the dissolution had been suspended, and now it was time to take a break" 80 .

After his confinement in Foros, Gorbachev returned to Moscow in the early hours of August 22. As a sincere optimist, he was hoping that the hardest of the trials were over. And yet, after his unfortunate holiday he returned to a country where he had no real

${ }^{73}$ Ialyshev R. A. "Novoogarevskii protsess" vyrabotki novogo soiuznogo dogovora vesnoi - letom 1991 g.: federatsiia ili konfederatsiia? // Mezhvuzovskaia nauchnaia konferentsiia "Rossiia v epokhu revoliutsii i reform: problemy istorii i istoriografii”. Sbornik dokladov. Sankt-Peterburg, 27 noiabria 2015. St. Petersburg, 2016. P. 279.

${ }^{74}$ On the development of the Union Treaty see.: Lukashin A. V. Razrabotka rukovodstvom SSSR Soiuznogo dogovora (mart - dekabr' 1991 goda): dis. ... kand. ist. nauk. Moscow, 2012. 253 p.

75 Dogovor o Soiuze Suverennykh gosudarstv // Pravda. 1991. 15 avgusta.

76 Interv'iu V. A. Mikhailova, v 1991 godu — zaveduiushchego otdelom mezhnatsional'nykh otnoshenii TsK KPSS (Moscow, 24.01.2018) // Arkhiv avtora.

77 Cherniaev A. Gorbachev ochen' dobryi...

78 Interv'iu V. N. Ignatenko (Moscow, 17.10.2018) // Arkhiv avtora; Interv'iu V. V. Kalashnikova (St. Petersburg, 31.10.2018) // Ibid.

79 Gorbachev M. S. Ostaius' optimistom. Moscow, 2017. P. 249.

${ }^{80}$ Interv'iu A. A. Bessmertnykh... 
power: the Centre had virtually collapsed in the three days of the coup ${ }^{81}$. The sagacious V. A. Medvedev, who rushed with presidential aide Oleg Ozherelyev to the airport to meet Gorbachev, uttered the prophetic words: "The coup is the end of Gorbachev as President. The end of his career" 82 . As Vladimir Lukin, who was a people's deputy of the Russian SFSR at the time, said, "Gorbachev came back, but power did not come with him"83.

Gorbachev had to face the new rules of the game: President of the Soviet Union was no longer free in his decisions and to a significant extent had to depend on El'tsin. El'tsin and Khasbulatov invited him to attend the extraordinary session of the Russian Supreme Soviet, which had begun the day before. Most probably he expected to be welcomed with triumph, but the reality, which the entire nation could see during the live broadcast, was that Gorbachev's speech was constantly interrupted by audience members and eventually turned into a degrading interrogation presided by El'tsin as the main winner of the August events ${ }^{84}$. As Ruslan Khasbulatov put it, "it was El'tsin's public revenge for all the humiliation he had suffered... Since then Gorbachev essentially was El'tsin's prisoner"85.

The public lashing showed the multi-million population that President of the USSR had no power any more, that he was no longer "tsar" 86 ; while Gorbachev was being "interrogated" by El'tsin and the people's deputies, the country could see that "the USSR de facto did not exist", remembered V.T. Tret'iakov, editor-in-chief of a major opposition newspaper Nezavisimaia Gazeta ${ }^{87}$. In order to "ease the tension" El'tsin issued a decree to suspend the activities of the Russian Communist Party as a force involved in the coup attempt.

Having dismantled the party apparatus, Eltsin and his team could start to demolish the USSR. The era of Gorbachev was declining. He lost much of his confidence; the three days in August had demoralized him ${ }^{88}$.

Gorbachev realized that after the coup attempt the balance of power was not in his favour. It was now not only by El'tsin's associates, but also by the Kremlin courtiers that he was not perceived as the boss of the enormous country. "Decomposition was in the air, Gorbachev looked shattered and defeated", such was the impression remembered by Alexander Bessmertnykh ${ }^{89}$.

It took four months and three days between Gorbachev's return from Foros and his resignation. Each of those days was filled with work, but everything was useless. And could it have been different? As Georgii Ostroumov, Director of Gorbachev's Secretariat, put it: "The attempt of the coup terrified all of the constituent republics. What if the same thing could happen to us? The republics began to split off, the Centre lost its authority"

${ }^{81}$ See more: Puchenkov A. S. Avgustovskii putch 1991 g.: vzgliad na sobytiia iz zdaniia TsK (po pokazaniiam ochevidtsev) // Noveishaia istoriia Rossii. T.9, no. 2. P. 454-484.

82 Ozherel'ev O. I. Idealy i prestupleniia. Noveishaia istoriia Rossii: dialektika sobytii. Moscow, 2016. P. 62.

${ }^{83}$ Interv'iu V.P. Lukina, narodnogo deputata RSFSR (Moscow, 22.03.2019) // Arkhiv avtora.

${ }^{84}$ Interv'iu N.I. Travkina, Geroia Sotsialisticheskogo Truda, narodnogo deputata SSSR i RSFSR (Moscow, 30.01.2019) // Ibid.

${ }^{85}$ Interv'iu R. I. Khasbulatova (Moscow, 12.08.2016) // Ibid.

${ }^{86}$ Interv'iu P. S. Filippova, narodnogo deputata RSFSR (St. Petersburg, 18.02.2019) // Ibid.

87 Interv'iu V.T. Tret'iakova (Moscow, 19.12.2018) // Ibid.

${ }^{88}$ Kalashnikov V. Avgust 91-go v lichnom formate // Sankt-Peterburgskie vedomosti. 2016. 21 oktiabria.

${ }^{89}$ Interv'iu A. A. Bessmertnykh...

90 Interv'iu G. S. Ostroumova, v 1991 godu — rukovoditelia Sekretariata Prezidenta SSSR (Moscow, 06.02.2018) // Arkhiv avtora. 
Ostroumov is echoed by S. B. Stankevich, El'tsin's adviser in 1991-1993, who is certain that after the coup attempt "the republics started to run away from Moscow"

Gorbachev knew that the only opportunity to prevent the final collapse of the country was to make a new union treaty at the earliest possible moment. This was extremely difficult to do: after the coup, the republics did not feel that they had any obligations towards the Centre. The unique opportunity of signing the New Union Treaty between the not-yet-discredited Centre and the republics had been lost because of the coup plotters, who unintentionally killed the USSR. August 18, 1991, when Gorbachev was isolated at the government dacha, "Zaria", and announced ill, became the point of no-return, the day of the true destruction of the Soviet Union. "After August 19 the Union disappeared in a day", remembered Boris El'tsin ${ }^{92}$. According to him, the coup not only undermined the adoption of the Union Treaty, but also resulted in the collapse of the Centre ${ }^{93}$. Stanislav Shushkevich, one of the Belovezh signatories, also believed that the collapse of the USSR "de facto took place in August 1991 after the defeat of the GKChP"94.

The immature and ill-considered actions of the GKChP made the adoption of the New Union Treaty highly unlikely; after the coup the power of the USSR President was in many ways a phantom, the political initiative was taken by El'tsin whose agenda was aimed at abolishing the Centre represented by Gorbachev. Against all odds Gorbachev managed to resume the Novo-Ogaryovo process, but now the outcomes completely depended on Russia and the Ukraine, whose leader Leonid Kravchuk was quite open and honest about his unwillingness to discuss the New Union Treaty in an interview to the Komsomolskaya Pravda newspaper: "The Centre has discredited itself. They say, the Centre will not be the same, and it will be created by the republics... And who did it use to be created by? I think if we are to undertake anything, it must be on a different, and I want to stress this, on an absolutely different foundation. The Novo-Ogaryovo process is over because of the GKChP. The new stage of our work implies creating something similar to the European Community"95. In another interview, Kravchuk indicated indirectly that he did not see any future in continuing the Novo-Ogaryovo process directed by Gorbachev ${ }^{96}$. At that time, the Centre de facto was in charge only of the foreign policy issues being detached from the domestic policy.

Gorbachev had to rely completely on El'tsin. The issue of preserving or not preserving a unified state depended directly on the "cornerstone component" of the union, i.e. Russia. It was clear that the possibility of the New Treaty was slim, but Gorbachev was trying to grasp at any straw in the hope to outplay El'tsin. His hope proved vain.

In November 1991 it became obvious that Russia was going to stall the Treaty as long as possible; it was also clear that El'tsin would not put up with any form of even a token supremacy of Gorbachev - the Ukraine was but an excuse for El'tsin in pursuing his ultimate goal, which was to remove Gorbachev from the Kremlin. Preserving a unified state was for him a secondary task in comparison with celebrating a conclusive triumph over the Soviet President, which could only be achieved by dismantling the Union and thus

${ }^{91}$ Interv'iu S. B. Stankevicha...

92 El'tsin B.N. Zapiski prezidenta. Moscow, 1994. P. 54.

93 El'tsin B. Proiskhodit obval soiuznogo Tsentra // Kuranty. 1991. 31 avgusta.

94 Shushkevich S. S. Moia zhizn', krushenie i voskreshenie SSSR. Moscow, 2012. P. 196.

${ }_{95}$ Kravchuk L. V dogovor s Rossiei ia veriu bol'she, chem v Soiuz // Komsomol'skaia pravda. 1991. 21 noiabria.

${ }^{96}$ Kravchuk L. Lider dolzhen podchinit'sia vyboru naroda // Izvestiia. 1991. 27 noiabria. 
leaving Gorbachev without his post. From this perspective, the position of Kravchuk, who did not want to sign the New Treaty either, worked to El'tsin's benefit. The Novo-Ogaryovo process had reached stalemate, and the USSR President's close associates started saying that "Gorbachev's efforts to save the Union were fruitless convulsions"97.

The results of the Ukraine's referendum on independence on 1 December 1991, were used by El'tsin and his team to announce that the Novo-Ogaryovo process hit a dead end. In the words of Gorbachev, "the moment with the Ukraine was used by Russia's leaders to their benefit" $"$. There was hardly any secret scheme between El'tsin and Kravchuk; it is much more likely that both of them felt it necessary to coordinate their efforts aimed at getting rid of the Centre's patronage. What the Ukraine and Russia did was de facto stand as one when they brought the autumn series of negotiations to a deadlock. The Belovezh Accords signed by the leaders of the three Slavic republics were the bottom line of the history of the USSR.

December 25, 1991 saw the end of the political career of the President of the USSR who announced his resignation. On that day the Soviet Union ceased to exist, and the constituent republics "set off on their own journeys" by starting a new phase in their history. "We ourselves destroyed the Soviet Union, not somebody else. So many right words were said - but only later. We had to make a decision then. What we decided is now history", remembered Gorbachev ${ }^{99}$. While Gorbachev has the historical responsibility for the dissolution of the Soviet Union, it must be stressed that the "empire" fell apart, the same way as it did in 1917, in full view of the indifferent people, who, by trademark Russian tradition, "were speechless" having no faith in the old rulers and not having yet lost their faith in the new ones.

Demoralized by the betrayal of the leaders of the Slavic republics, Gorbachev failed to take productive measures to save the Union. Loyal to his credo, he did not go beyond admonishments and carried on his struggle "for preserving a unified state through political - I want to stress the word, political - methods"; he blames the Belovezh signatories for the "mindless and opportunistic dissolution of the Union"100, but is not ready to take his part of the responsibility.

An immense role in the dissolution of the USSR was played by a whole array of factors: the public being tired of the Communist project; the massive shortages of consumer goods, which made people hate the government; the growing opposition within the Communist party to Gorbachev's reforms; the hesitation of the General Secretary who tried to rely in turn either on the right or on the left wing; the drastic fall in the living standards. However, the crucial role was played by "the parade of sovereignties" and the Centre being too late in its attempts to address the national question.

\section{References}

Atamanchuk G.V. A New State: the Quest, the Illusion of Opportunity. Moscow, Slavianskii dialog Publ., 1996, 221 p. (In Russian)

${ }_{97}$ Cherniaev A.S. Dnevnikovaia zapis' ot 26 noiabria 1991 g. // Cherniaev A. S. Sovmestnyi iskhod. P. 1027.

98 Gorbachev M. Dai bog, chtob ia oshibsia // Komsomol'skaia pravda. 1991. 13 dekabria.

99 Gorbachev M. Nado izmenit' atmosferu // Ogonek. 2015. No. 4. P. 19.

100 Mikhail Gorbachev — Vitaliiu Tret'iakovu: Predlagaemaia Vami rol' «prositelia» mne ne podkhodit // Komsomol'skaia pravda. 2014. 13 marta. 
Brown A. The Gorbachev Factor. Oxford, Oxford University Press, 1997, 406 p.

Lukashin A. V. Development by the USSR Leadership of the Union Treaty (March - December 1991). Diss. ... kand. ist. nauk. Moscow, [S.n.], 2012, 253 p. (In Russian)

Pikhoia R. G. About the Periodization of the systemic Crisis of the Soviet Union. Rossiiskaia istoriia, 2019, no. 2, pp. 3-39. (In Russian)

Puchenkov A.S. August Putsch 1991: a Look at the Events of the Central Committee Building (according to Eyewitnesses). Noveishaia istoriia Rossii, 2019, vol.9, no. 2, pp.454-484. (In Russian)

Puchenkov A.S. Victories and Defeats of Mikhail Gorbachev. Rossiiskaia istoriia, 2019, no. 2, pp. 205-213. (In Russian)

Puchenkov A.S. The life and times of Anatolii Cherniaev. "My nazyvali ego grafom": Pamiati Anatoliia Sergeevicha Cherniaeva. Vospominaniia sovremennikov, dokumenty, publikatsii. Moscow, Liubimaia Rossiia Publ., 2019, pp.511-565. (In Russian)

Stankevich Z. A. Soviet Union. The Break of History. Moscow, Knizhnyi mir Publ., 2016, 708 p. (In Russian)

Taubman U. Gorbachev. His Life and Time. Moscow, AST; Corpus Publ., 2019, 768 p. (In Russian)

Shubin A.V. The main Problems and Stages of the History of Perestroika. Rossiiskaia istoriia, 2019, no.2, pp.39-51. (In Russian)

Yalyshev R. A. "Novoogarevo Process" of Establishing a New Union Treaty in Spring - Summer 1991: Federation or Confederation? Mezhvuzovskaia nauchnaia konferentsiia "Rossiia v epokhu revoliutsii i reform: problemy istorii i istoriografii”. St. Petersburg, Izd-vo SPbGETU “LETI” Publ., 2016, pp. 262-279. (In Russian)

Yalyshev R. A. The Problem of the new Union Treaty and its Role in the Collapse of the USSR. Diss. ... kand. ist. nauk. St. Petersburg, [s.n.], 2011, 270 p. (In Russian)

Zubok V.M. Crisis, Reforms and Destruction of the USSR. Rossiiskaia istoriia, 2019, no. 2, pp.30-39. (In Russian)

Zubok V. M. Failed Empire: the Soviet Union in the Cold War from Stalin to Gorbachev. Moscow, ROSSPEN Publ.; Fond "Prezidentskii tsentr B. N. El'tsina” Publ., 2011, 671 p. (In Russian)

Статья поступила в редакцию 25 сентября 2019 г.

Рекомендована в печать 8 июня 2020 г.

Received: September 25, 2019

Accepted: June 8, 2020 